\title{
LIGHT CONDITIONS AFFECT NaCI-INDUCED PHYSIOLOGICAL RESPONSES IN A CLONAL PLANT SPECIES HYDROCOTYLE VULGARIS
}

\author{
Ineta Samsone ${ }^{1}$, Una Andersone-Ozola ${ }^{1}$, Andis Karlsons ${ }^{2}$, and Gederts levinsh ${ }^{1}{ }^{1}$ \\ ${ }^{1}$ Faculty of Biology, University of Latvia, Jelgavas iela 1, Rīga, LV-1004, LATVIA \\ 2 Institute of Biology, University of Latvia, Miera iela 3, Salaspils, LV-2169, LATVIA \\ \# Corresponding author, gederts.ievins@lu.lv
}

Communicated by Ina Alsiṇa

\begin{abstract}
In order to understand if differences in light conditions can affect responses of a clonal plant species to increased soil salinity, the long-term effect of two substrate concentrations of $\mathrm{NaCl}$ on leaf growth, clonal plasticity and oxidative enzyme (peroxidase and polyphenol oxidase) activity in Hydrocotyle vulgaris L. plants grown at low, moderate and high light conditions was studied. $\mathrm{H}$. vulgaris appeared to be a shade-tolerant species, since both leaf blade and petiole growth was inhibited at low light intensity. At low light intensity, $\mathrm{H}$. vulgaris plants represented characteristics of halophytes with significant stimulation of leaf blade and petiole growth by $\mathrm{NaCl}$, especially at low concentration. Secondary clonal growth was stimulated by increased salinity in low light and, for $25 \mathrm{mM} \mathrm{NaCl}$ treatment, even in moderate light. There was more than a five-fold increase of peroxidase activity by $100 \mathrm{mM} \mathrm{NaCl}$ treatment in high light conditions, in comparison to two-fold and four-fold increase in low and moderate light, respectively. The existence of different endogenous control mechanisms during $\mathrm{H}$. vulgaris response to light and $\mathrm{NaCl}$ at the level of leaf growth, clonal growth and oxidative metabolism could be proposed. The possible ecological meaning of the presented results is discussed in detail.
\end{abstract}

Key words: clonal growth, coastal habitats, oxidative enzymes, peroxidase, polyphenol oxidase, salinity.

\section{INTRODUCTION}

In coastal wetlands, fluctuating soil salinity is one of the most important environmental factors affecting plant growth and survival (Packham and Willis, 1997). Along with salinity, competitive processes, i.e. competition for light, is especially important for plant survival in extremely heterogeneous habitats such as salt marshes (Ungar, 1998). In this respect, one of the most intriguing questions is if light quantity and/or quality can affect plant response to increased soil salinity.

Physiological response of coastal wetland plants to salinity at different light levels has been studied recently with a number of species. However, contradictory data on the possible effect of light on salinity responses have been obtained. For example, salinity and light interactively affected growth of mangrove seedlings (López-Hoffman et al., 2007) in a manner that growth increase by light availability was more at low than high salinity. Interaction between light and salinity affecting overall performance of a salt marsh plant Aster laurentianus was strictly additive with no significant interaction between the factors (Reynolds et al., 2001). However, synergistic suppressive effects of salinity and high light on photosynthesis of Mesembryanthemum crystallinum (Broetto et al., 2007) and mangrove seedlings (Rochelle, 2005) have been reported. In contrast, high salinity had more severe consequences on growth at low light in comparison to those in high light for salt marsh grass Spartina alterniflora (Longstreth and Strain, 1977). However, no studies so far have described light-salinity interactions in a shade-tolerant species.

Plants with clonal growth forms are widespread in aquatic environments, including coastal areas (Santamaría, 2002; Sosnová et al., 2010). Clonal plants are acknowledged as important models for understanding ecosystem functioning (Cornelissen et al., 2014). Several studies so far have fo- 
cused on salinity effects on clonal plants (Rogers and West, 1993; Van Zandt et al., 2003; Richards et al., 2004). While it is well known that clonal growth characteristics are strongly affected by light intensity and quality (Dong, 1995; Liu et al., 2007), there is no information available on the effect of salinity on growth of clonal plants at different light levels.

Hydrocotyle represents a cosmopolitan genus of approximately 130 perennial clonal plant species mostly distributed in moist habitats. In studies on various aspects of ecophysiology in Hydrocotyle species, it was concluded that environmental changes result in a high morphological plasticity of plants (Peterson and Chesson, 2002; Knight and Miller, 2004; Dawe and Reekie, 2007). In particular, Hydrocotyle vulgaris $\mathrm{L}$. was described as a species being able to occupy a wide ecological amplitude due to high adaptability and phenotypic plasticity (Miao et al., 2011).

In the present study $H$. vulgaris was used as a model species. In contrast to Dong (1995), who described H. vulgaris as growing exclusively in open habitats, in the Baltic region $H$. vulgaris has characteristics of a putative shade tolerant species growing both under trees and in wet coastal grassland. In the coastal area of the Baltic Sea, H. vulgaris plants are present in habitats with seawater inundation-dependent relatively moderate fluctuations of soil salinity within a season, with soil electrical conductivity ranging from 0.71 to $12.80 \mathrm{dS} \cdot \mathrm{m}^{-1}$, and a wide range of light conditions (from deep tree canopy shade to full sun; Ievinsh et al., unpublished data). Therefore, it can be expected that both fluctuating salinity and light conditions affect growth and development of $H$. vulgaris in natural conditions.

Increased salinity induces various biochemical responses of possible adaptive character in plant tissues. Among them, changes in oxidative metabolism are generally well known (Shevyakova et al., 2006; Gapinska et al., 2008; Muchate et al., 2016). The aim of the present experiments was to study the long-term $\mathrm{NaCl}$ effect on morphological plasticity and oxidative enzyme (peroxidase and polyphenol oxidase) activity in $H$. vulgaris plants grown at different light conditions. Peroxidase and polyphenoloxidase activity was used as an indicator of $\mathrm{NaCl}$-induced changes of oxidative metabolism that possibly reflect biochemical plasticity of $H$. vulgaris plants. It was hypothesised that (i) $H$. vulgaris has the characteristics of a shade-tolerant species; (ii) effect of $\mathrm{NaCl}$ treatment depends on light conditions; and (iii) interaction between light and $\mathrm{NaCl}$ differentially affect leaf growth, clonal growth, and oxidative metabolism.

\section{MATERIALS AND METHODS}

Plant material and treatments. Stock plant material was introduced in culture from one genet of naturally growing Hydrocotyle vulgaris L. plants during summer and maintained in controlled conditions. For experiments, plants were propagated in the laboratory during early spring and represented a genetically identical clonal material. The ex- periment was started at the beginning of May. As starting material, five small plants with three ramets each were planted in a $30 \times 40 \mathrm{~cm}$ plastic trays filled with commercial neutralised peat with mineral nutrients (NPK 14-16-18).

Four light regimes were used in the experiments: first, low light provided by one fluorescent lamp with a photon flux density of $45 \mu \mathrm{mol} \cdot \mathrm{m}^{-2} \cdot \mathrm{s}^{-1}$ at the plant level; second, simulated canopy shade provided by three fluorescent lamps through a green plastic filter, with a photon flux density of $45 \mu \mathrm{mol} \cdot \mathrm{m}^{-2} \cdot \mathrm{s}^{-1}$ at the plant level (indicated as $45 \mathrm{~F}$ ); third, moderate light with a photon flux density of 120 $\mu \mathrm{mol} \cdot \mathrm{m}^{-2} \cdot \mathrm{s}^{-1}$ at the plant level provided by the same three fluorescent lamps; and fourth, natural daylight in a greenhouse with a photon flux density of $600-800 \mu \mathrm{mol} \cdot \mathrm{m}^{-2} \cdot \mathrm{s}^{-1}$ at the plant level. For low and moderate light treatments, a photoperiod of 16/8 h of light/dark was used. Plants for the first three light regimes were cultivated in the laboratory in a growth cabinet with day/night temperature of $23 / 188{ }^{\circ} \mathrm{C}$, air humidity $70 \%$. Plants for the natural daylight regime were grown in a glass greenhouse with supplemented night heating, average day/night temperature was $25 / 15{ }^{\circ} \mathrm{C}$. Plants were watered three times a week with deionised water.

Plants were allowed to grow for two weeks after planting. Then, the $\mathrm{NaCl}$ concentration in the substrate was increased gradually during a week using watering solution with increasing $\mathrm{NaCl}$ concentration $(25 \mathrm{mM}$ per day). After that, plants were watered with 0,25 or $100 \mathrm{mM} \mathrm{NaCl}$ twice a week. For each treatment, five replicates (individual trays) with five plants each were used.

Morphological measurements. Plants were harvested at five weeks after the start of the $\mathrm{NaCl}$ treatment. Each genet was carefully separated from the substrate, washed under running water and clonal growth parameters were measured. Stolons formed on an initial mother plant during the experiment were designated as primary stolons. Branching of the primary stolons formed secondary stolons. Petiole length, fresh mass and leaf blade diameter and fresh mass were measured for fully-grown leaves on ramets formed on a primary stolon. For each of five biological replicates per treatment, 30 to 50 leaf measurements were performed.

For analysis of specific leaf area, 30 leaf blades were dried at $70{ }^{\circ} \mathrm{C}$ until constant weight. Specific leaf area was calculated as the ratio between leaf area and leaf dry mass.

$\mathrm{Na}^{+}$analysis. Plant tissues were dried in an oven $\left(60{ }^{\circ} \mathrm{C}\right)$, weighed and ground into a fine powder using a ball mill. The samples were dry-ashed in concentrated $\mathrm{HNO}_{3}$ vapour and redissolved in $\mathrm{HCl}$ solution $(\mathrm{HCl}$ : deionized water 3 : $100, v / v)$ and analysed for Na concentration. Substrate samples for $\mathrm{Na}$ analysis were air-dried and sieved through a metal sieve (2-mm mesh size). Samples were extracted with $1 \mathrm{mM} \mathrm{HCl}$ in a $1: 5$ soil to extractant volume ratio. $\mathrm{Na}^{+}$was measured by a flame photometer PFP7 (Jenwey) with an air-propane/butane flame. Five replicates per treatment were analysed. 
Enzyme analysis. For measurement of enzyme activities, leaf blades and leaf petioles were rinsed with deionised water, frozen in liquid nitrogen and stored at $-80{ }^{\circ} \mathrm{C}$ until analysis. For extraction of enzymes, leaf tissues were ground in liquid nitrogen and extracted with $25 \mathrm{mM}$ HEPES ( $\mathrm{pH} 7.2$ ) containing $1 \mathrm{mM}$ EDTA and $3 \%$ insoluble polyvinylpolypyrrolidone for $15 \mathrm{~min}$ at $4{ }^{\circ} \mathrm{C}$. The homogenate was filtered through nylon cloth and centrifuged at 15000 $\mathrm{g}_{\mathrm{n}}$ for $15 \mathrm{~min}$. Guaiacol peroxidase (EC 1.11.1.7) activity was determined in a reaction mixture $(3 \mathrm{ml}$ containing 0.05 $\mathrm{M}$ potassium phosphate $(\mathrm{pH} 7.0), 15 \mathrm{mM}$ guaiacol, 0.03 $\mathrm{mM}$ hydrogen peroxide, and $20 \mu \mathrm{l}$ of the enzyme extract. The activity was determined by monitoring the increase in absorbance at $470 \mathrm{~nm}$ following tetraguaiacol formation (Maehly and Chance, 1954) and expressed as increase of absorbance in $1 \mathrm{~min}$ per $1 \mathrm{~g}$ fresh mass. Diphenolase (EC 1.10.3.2) activity of polyphenol oxidase was measured according to Gauillard et al. (1993). The reaction mixture (3 $\mathrm{ml}$ ) contained $25 \mathrm{mM}$ pyrocatechol in $0.1 \mathrm{mM}$ potassium phosphate (pH 6.5) and $10 \mu \mathrm{l}$ of the enzyme extract. The increase in absorbance at $410 \mathrm{~nm}$ was monitored and activity was expressed as increase of absorbance in 1 min per $1 \mathrm{~g}$ fresh mass. For enzyme measurement, one pooled sample of either leaf blades or petioles per biological replicate (five in total per treatment) was analysed.

Data analysis. Separate parallel experiments with respective controls were performed for $H$. vulgaris in laboratory (low and moderate light treatments) and in greenhouse conditions (high light treatment). Significant differences between the parameters at all treatments were determined at $p<0.05$ by a Tukey-Cramer test.

\section{RESULTS}

Watering of $H$. vulgaris plants with increased $\mathrm{NaCl}$ concentration in watering solution led to accumulation of excess $\mathrm{Na}^{+}$in the substrate (Table 1). Tissue concentrations of $\mathrm{Na}^{+}$ increased in parallel with increase in substrate $\mathrm{Na}^{+}$indicating uptake of ions. The increase in $\mathrm{Na}^{+}$was more pronounced in leaf blade tissues as compared to leaf petiole tissues. A significantly lower amount of $\mathrm{Na}^{+}$accumulated in stolon tissues.

Light conditions significantly affected both leaf growth of $H$. vulgaris as well as the effect of $\mathrm{NaCl}$ on the leaf growth. Maximum leaf blade and leaf petiole growth of control plants was evident at moderate light intensity (120 $\mu \mathrm{mol} \cdot \mathrm{m}^{-2} \cdot \mathrm{s}^{-1}$ ) (Figs. 1, 2). Leaf blade diameter and both petiole length and fresh mass were significantly lower at high light intensity $\left(600-800 \mu \mathrm{mol} \cdot \mathrm{m}^{-2} \cdot \mathrm{s}^{-1}\right)$, compared to moderate light intensity. In control plants, specific leaf area decreased with increase of light intensity (Fig. 1C). However, the difference was not statistically significant between moderate and low light intensity $\left(45 \mu \mathrm{mol} \cdot \mathrm{m}^{-2} \cdot \mathrm{s}^{-1}\right)$.

The effect of $25 \mathrm{mM} \mathrm{NaCl}$ on leaf growth characteristics gradually changed from stimulation to inhibition under increasing light intensity from 45 to $600-800 \mu \mathrm{mol} \cdot \mathrm{m}^{-2} \cdot \mathrm{s}^{-1}$. Higher $\mathrm{NaCl}$ concentration $(100 \mathrm{mM})$ had no effect on leaf growth at low light intensity, except for leaf petiole length, which was stimulated by $\mathrm{NaCl}$ (Fig. 2A). Both at moderate and high light intensities, $100 \mathrm{mM} \mathrm{NaCl}$ significantly inhibited all aspects of leaf growth. Specific leaf area was not significantly affected by $\mathrm{NaCl}$ treatment, except for a sig-

Table 1. Concentration of $\mathrm{Na}^{+}$in substrate and Hydrocotile vulgaris tissues at different $\mathrm{NaCl}$ treatments 5 weeks after the start of the experiment

\begin{tabular}{|c|c|c|c|c|}
\hline $\mathrm{NaCl}(\mathrm{mM})$ & Substrate $\mathrm{Na}^{+}(\mathrm{mM})$ & Leaf blade $\mathrm{Na}^{+}\left(\mathrm{mmol} \cdot \mathrm{kg}^{-1}\right)$ & Leaf petiole $\mathrm{Na}^{+}\left(\mathrm{mmol} 1 \cdot \mathrm{kg}^{-1}\right)$ & Stolon $\mathrm{Na}^{+}\left(\mathrm{mmol} 1 \cdot \mathrm{kg}^{-1}\right)$ \\
\hline 0 & $5 \pm 0 \mathrm{a}$ & $0.013 \pm 0.001 \mathrm{a}$ & $0.017 \pm 0.001 \mathrm{a}$ & $0.014 \pm 0.001 \mathrm{a}$ \\
\hline 25 & $132 \pm 9 b$ & $0.099 \pm 0.005 b$ & $0.059 \pm 0.003 b$ & $0.023 \pm 0.001 b$ \\
\hline
\end{tabular}

Plants were cultivated at $120 \mu \mathrm{mol} 1 \cdot \mathrm{m}^{-2} \cdot \mathrm{s}^{-1}$ in a growth cabinet. Different letters indicate significant differences due to salinity treatment $(p<0.05)$
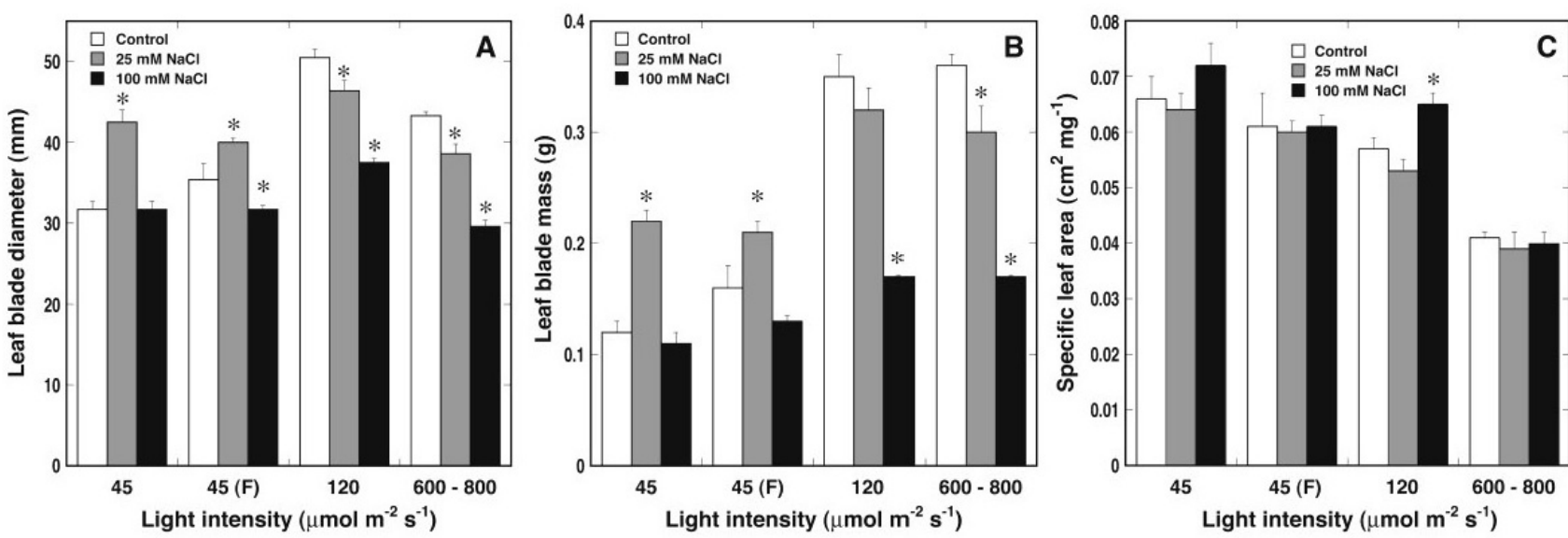

Fig. 1. Effect of $\mathrm{NaCl}$ treatment and light intensity on leaf blade diameter (A), leaf blade fresh mass (B) and specific leaf area (C) of Hydrocotyle vulgaris. Plants were analysed 5 weeks after the start of the treatment with $\mathrm{NaCl}$. Data are means $+\mathrm{SE}$ from 5 biological replicates with 30 to 50 measurements per replicate. $45(\mathrm{~F})$ indicates light filtered through a green plastic filter. $(*)$, significant differences from control due to salinity treatment for a particular light treatment $(p<0.05)$. 

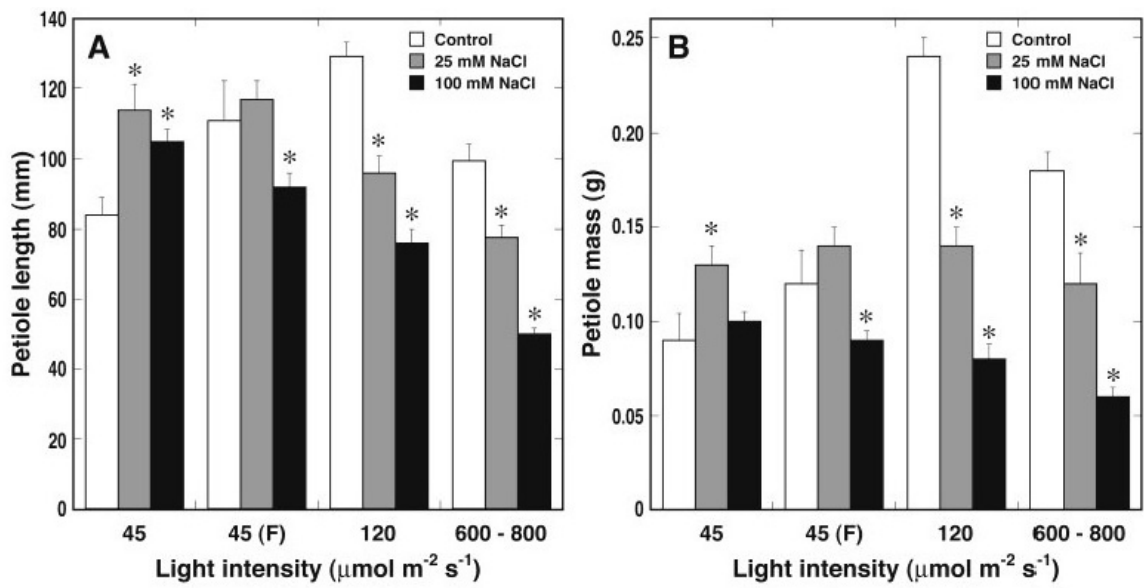

Fig. 2. Effect of $\mathrm{NaCl}$ treatment and light intensity on leaf petiole length (A) and leaf petiole fresh mass (B) of Hydrocotyle vulgaris. Plants were analysed 5 weeks after the start of the treatment with $\mathrm{NaCl}$. Data are means $+\mathrm{SE}$ from 5 biological replicates with 30 to 50 measurements per replicate. 45 (F) indicates light filtered through a green plastic filter. $(*)$, significant differences from control due to salinity treatment for a particular light treatment $(p<0.05)$.
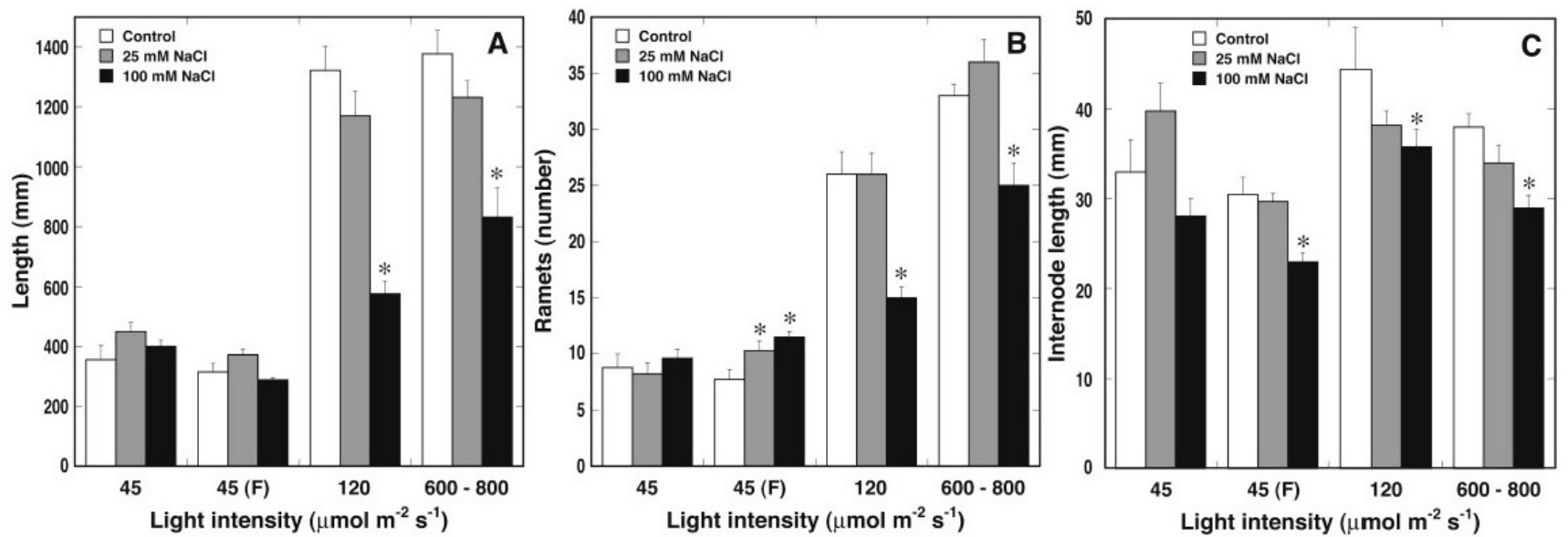

Fig. 3. Effect of $\mathrm{NaCl}$ treatment and light intensity on length of primary stolons (A), number of ramets on primary stolons (B), and internode length of primary stolons (C) of Hydrocotyle vulgaris. Plants were analysed 5 weeks after the start of the treatment with $\mathrm{NaCl}$. Data are means $+\mathrm{SE}$ from 5 biological replicates with 5 measurements per replicate. 45 (F) indicates light filtered through a green plastic filter. $\left.{ }^{*}\right)$, significant differences from control due to salinity treatment for a particular light treatment $(p<0.05)$.
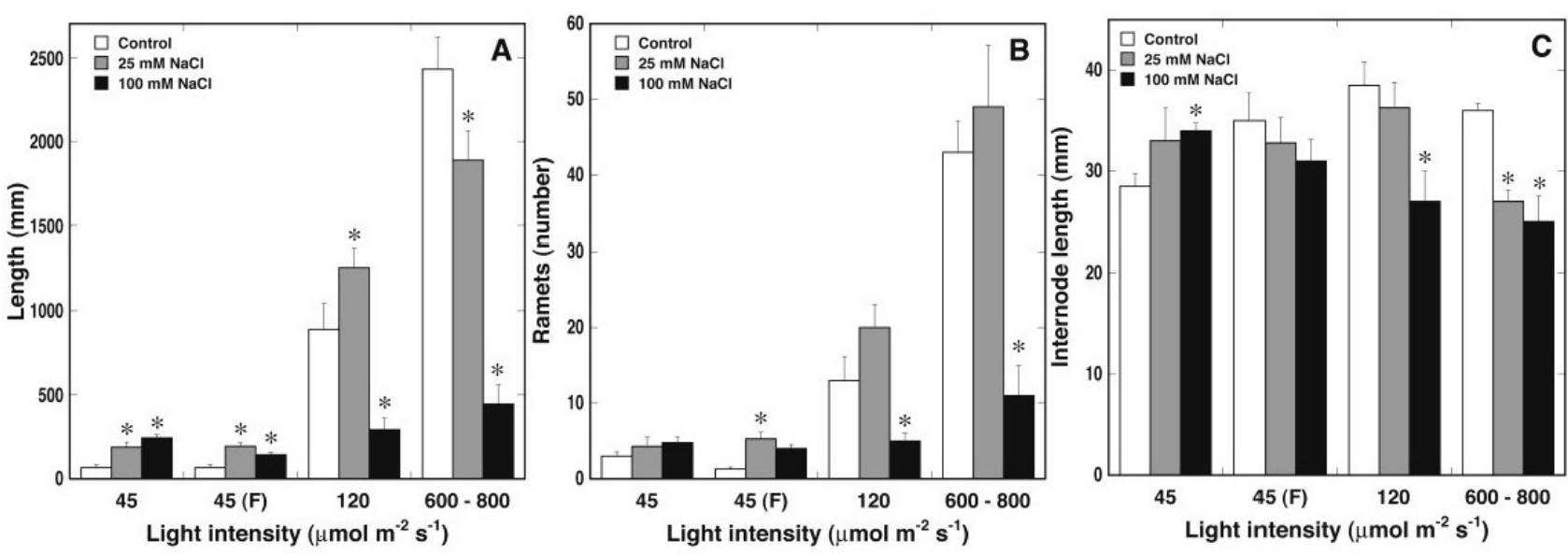

Fig. 4. Effect of $\mathrm{NaCl}$ treatment and light intensity on length of secondary stolons (A), number of ramets on secondary stolons (B), and internode length of secondary stolons $(\mathrm{C})$ of Hydrocotyle vulgaris. Plants were analysed 5 weeks after the start of the treatment with $\mathrm{NaCl}$. Data are means $+\mathrm{SE}$ from 5 biological replicates with 5 measurements per replicate. $45(\mathrm{~F})$ indicates light filtered through a green plastic filter. $(*)$, significant differences from control due to salinity treatment for a particular light treatment $(p<0.05)$.

nificant increase by $100 \mathrm{mM} \mathrm{NaCl}$ treatment at 120 $\mu \mathrm{mol} \cdot \mathrm{m}^{-2} \cdot \mathrm{s}^{-1}$ (Fig. 1C).

Clonal characteristics of $H$. vulgaris were dramatically affected by the light conditions (Figs. 3, 4). Both growth of primary stolons and the number of primary ramets were significantly inhibited at low light intensity in comparison to moderate light (Fig. 3A, B). However, these parameters were less affected by increase of light intensity from moderate to high. In contrast, internode length of primary stolons was relatively little increased by increase of light intensity from low to moderate and even inhibited by further increase to high intensity (Fig. 3C). Growth of secondary stolons and development of secondary ramets on the stolons was gradu- 
ally stimulated by increase of light intensity from low to moderate and further to high light. Internode length of secondary stolons also was increased by increasing light intensity (Fig. 4C). However, the effect was not statistically significant.

$\mathrm{NaCl}$ at 25 and $100 \mathrm{mM}$ in low light conditions had relatively small effect on primary growth characteristics, while $100 \mathrm{mM} \mathrm{NaCl}$ was inhibitory at both moderate and high light intensity. However, the development of secondary stolons and ramets was stimulated by $25 \mathrm{mM} \mathrm{NaCl}$ at low and moderate light intensity. At moderate and high light intensity, secondary development was significantly inhibited by $100 \mathrm{mM} \mathrm{NaCl}$, while stimulation was evident at low light intensity. Internode length of both primary and secondary stolons was relatively less affected by light intensity and was inhibited by $\mathrm{NaCl}$ at moderate and high light intensity (Figs. 3C, 4C).

Leaf petiole tissues of $H$. vulgaris had relatively lower oxidative enzyme activity than leaf blade tissues (Fig. 5, 6). Oxidative enzyme activities in general were less affected by light conditions than were morphological characteristics. Moderate and high light suppressed peroxidase activity in leaf blade tissues of control plants in comparison to low light (Fig. 5A). In contrast, polyphenol oxidase activity was stimulated by high light in the leaf blades (Fig. 6A). Treatment with $\mathrm{NaCl}$ stimulated peroxidase activity both in leaf blades and petioles (Fig. 5). The stimulative effect was especially pronounced in leaf petioles treated with $100 \mathrm{mM}$
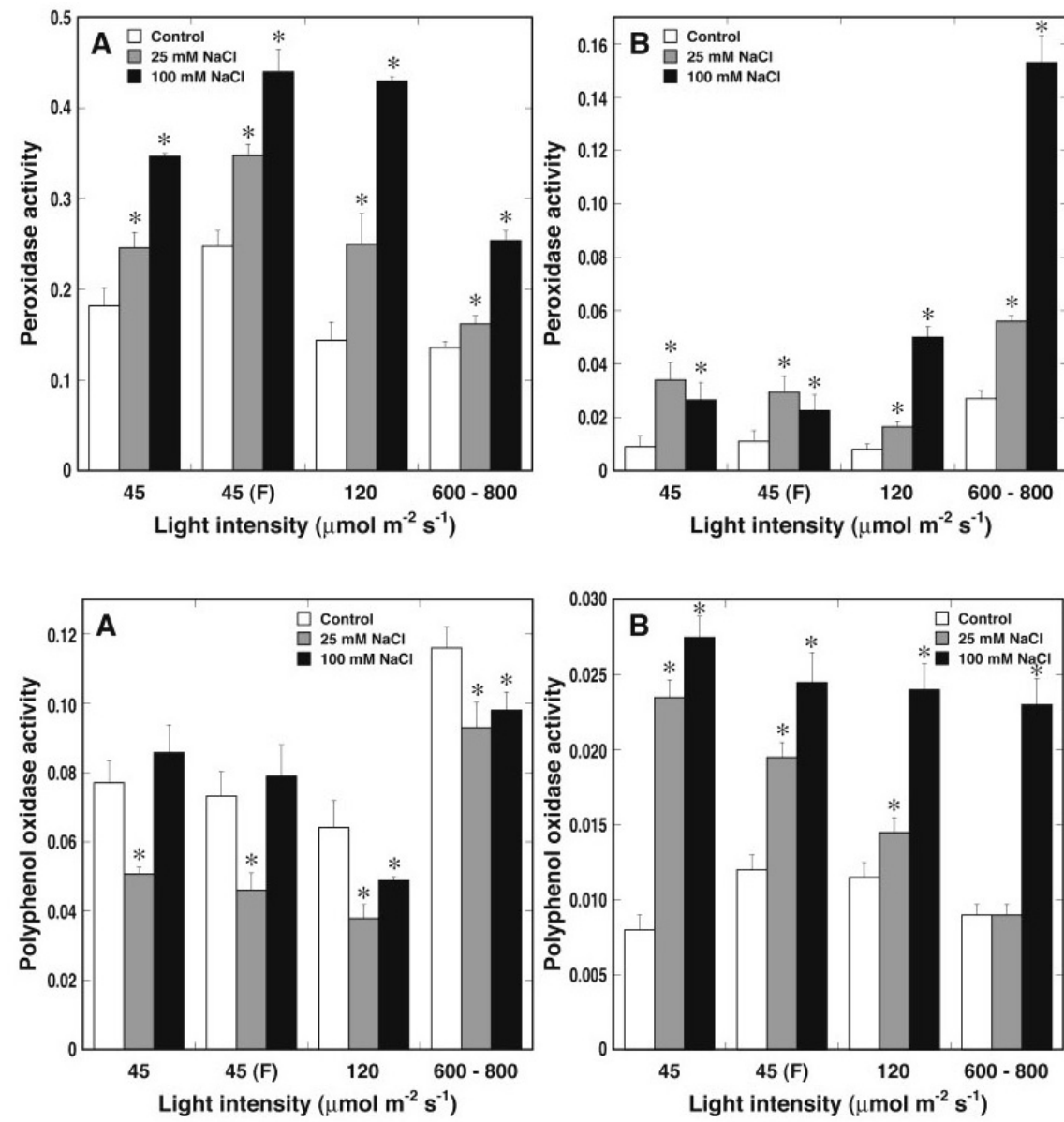

Fig. 6. Effect of $\mathrm{NaCl}$ treatment and light intensity on polyphenol oxidase activity in leaf blades (A) and leaf petioles (B) of Hydrocotyle vulgaris. Enzyme activity was expressed as an increase of absorbance in $1 \mathrm{~min}$ per $1 \mathrm{~g}$ fresh mass. Plants were analysed 5 weeks after the start of the treatment with $\mathrm{NaCl}$. Data are means + SE from 5 biological replicates. 45 (F) indicates light filtered through a green plastic filter. $(*)$, significant differences from control due to salinity treatment for a particular light treatment $(p<$ $0.05)$. 
When characterising physiological responses of the model plant, $H$. vulgaris, in respect to salinity and changes in light intensity, it is evident that while growing in the wild on a wide range of substrate salinity, $H$. vulgaris represents a relatively salt tolerant species, as tissue ion status is tightly regulated by preferential accumulation of $\mathrm{Na}^{+}$and $\mathrm{Cl}^{-}$in the leaf blade and petiole tissues with no increase of the ion concentration in stolons (Karlsons et al., 2008). Evidently, osmotic balance in stolon tissues is maintained by accumulation of compatible osmolites, mostly proline, as described also for other species (Ben Ahmed et al., 2008; Karlsons et al., 2011). However, limited salinity tolerance of $H$. vulgaris is illustrated by the fact that ion accumulation is clearly saturable at moderate substrate $\mathrm{NaCl}$ level $\left(4 \mathrm{~g} \cdot \mathrm{l}^{-1}\right)$, while an obligate halophyte Aster tripolium did not show saturation even at 15 to $20 \mathrm{~g} \cdot \mathrm{l}^{-1} \mathrm{NaCl}$ substrate concentration (Karlsons et al., 2008).

When glycophytic species are considered, initial growth inhibition by high salinity is related to direct osmotic effects with little species-specific differences (Neumann, 1997). The differences are expected to appear only after weeks or months due to the direct effect of salt accumulated in tissues at different concentrations. The effect of light and air humidity on salinity tolerance was studied in glycophytic Solanum tuberosum plants (Backhausen et al., 2005). Higher transpiration rate in conditions of higher light intensity or lower air humidity resulted in faster ion uptake and, as a consequence, development of $\mathrm{NaCl}$-dependent oxidative stress in cells. Halophytic plants clearly do not have endogenous $\mathrm{NaCl}$ concentration-dependent growth inhibition because of $\mathrm{NaCl}$ sequestration in the vacuole. Consequently, NaCl-dependent growth stimulation vs. growth inhibition mechanisms in halophytes are far from clear. Stimulation of $H$. vulgaris growth in shade by low concentration of $\mathrm{NaCl}$ could be similar to the growth stimulation mechanism by $\mathrm{NaCl}$ characteristic of true halophytes. Consequently, at low light intensity, $H$. vulgaris plants represent characteristics of halophytes with significant stimulation of leaf blade and petiole growth, especially, at low salinity. Also, secondary clonal growth was stimulated by increased salinity in low light and even moderate light (for $25 \mathrm{mM}$ $\mathrm{NaCl}$ ) conditions. What might be a possible mechanism of growth stimulation by low $\mathrm{NaCl}$ in low light conditions? A tempting explanation could be involvement of biochemical defence mechanisms relatively unaffected by changes in light conditions, i.e. antioxidative system involving peroxidase or polyphenol oxidase, which both were stimulated by $\mathrm{NaCl}$. As a result, protection of photosynthesis against osmotic stress-dependent production of reactive oxygen species may lead to higher photosynthetic productivity and/or growth stimulation.

Light as an environmental factor had two main consequences in the context of our experiments. Firstly, light changed morphology and, to a lesser extent, biochemistry of oxidative processes of control plants. Both leaf growth and clonal growth was strongly affected by light conditions. Clonal growth and especially secondary stolon formation were sensitive to low light. In contrast to shade-intolerant species that show significant elongation of organs of vertical axis in shaded conditions (Mommer et al., 2005), shade tolerant species invest in increase of leaf photosynthetic area (Gommers et al., 2013). In contrast to morphological parameters, oxidative enzyme activity was less affected by light intensity. Secondly, effect of $\mathrm{NaCl}$ on morphology and biochemical parameters was light-dependent. Light $/ \mathrm{NaCl}$ interaction was especially pronounced at low salinity (25 $\mathrm{mM} \mathrm{NaCl})$.

Two typical strategies of herbaceous plants in respect to behaviour in low light conditions are known, representing possible adaptive response of plants to decreased light intensity — shade avoidance and shade tolerance. Shade-induced elongation of petioles is a characteristic morphological feature of shade avoiding species (Huber and Wiggerman, 1997). In contrast, shade tolerant or shade acclimating species tend to have shorter petioles in conditions of decreased light intensity in parallel with an increase in specific leaf area (Reich et al., 1998). However, it is shown that the increase of specific leaf area in shaded conditions is not necessary accompanied by a concomitant increase of petiole length. Moreover, petiole length was shown to increase due to shading only in one species of three in the genus Convolvulus, which was particularly adapted to open or partially open sites, in spite of increased specific leaf area for all of the tested species (González and Gianoli, 2004).

The present results clearly characterise $H$. vulgaris as a shade acclimating (shade tolerant) species, since both leaf blade and petiole growth were inhibited at low light intensity (Fig. 1A, 2A) and specific leaf area increased with decreased light intensity. This is in contradiction with previous studies with $H$. vulgaris, which showed a typical shade-avoidance response of the species (Dong, 1995; Leeflang et al., 1998), as both homogenous shade and vertical light gradient conditions induced significant petiole elongation. However, the area of leaf blades of $H$. vulgaris decreased in the shade, similar to our data. Also, in the present experiment, some stimulation of leaf blade and petiole growth was evident at moderate light intensity (120 $\mu \mathrm{mol} \cdot \mathrm{m}^{-2} \cdot \mathrm{s}^{-1}$ ) when compared to high light (400-600 $\left.\mu \mathrm{mol} \cdot \mathrm{m}^{-2} \cdot \mathrm{s}^{-1}\right)$. The latter might be regarded as a moderate light-induced shade avoidance response. Unfortunately, no data on actual light intensity measurements were given by Dong (1995) and Leeflang et al. (1998), therefore, it is difficult to compare these data with those of the present experiments. In addition, petiole length of $H$. vulgaris was extremely small in the experiments of Dong (1995), ranging from $1 \mathrm{~cm}$ (full light) to $5.5 \mathrm{~cm}$ (deep shade), as compared to 8.3 and $12.4 \mathrm{~cm}$ in the present study, in low and moderate light conditions, respectively. Besides, $H$. vulgaris has an optimum net photosynthesis at $350 \mu \mathrm{mol}$ photons $\mathrm{m}^{-2} \cdot \mathrm{s}^{-1}$ (Hussner and Lösch, 2007), indicating most efficient photosynthetic productivity in moderately shaded conditions.

Most likely, the shade response of $H$. vulgaris (shade avoidance vs. shade tolerance) depends on the genetic background, developmental stage of plants, seasonal factors etc. 
as it was shown that the two strategies are not necessarily mutually exclusive (Smith, 1982). In the context of the present experiments, it is convincing that not only light conditions per se but rather the character of shade response should be taken into the account when considering the effect of $\mathrm{NaCl}$ on plant performance in natural conditions.

High morphological and biochemical plasticity induced by changes in light conditions and increased substrate salinity were found in the present experiments. In respect to growth characteristics, $\mathrm{NaCl}$ acted towards diminishing lightdependent morphological changes. When low light resulted in inhibition of growth, as seen for leaf blade diameter and petiole length, low $\mathrm{NaCl}$ counteracted this effect. Moreover, the effect of $\mathrm{NaCl}$ on oxidative metabolism was clearly stimulative in both leaf blades and petioles for peroxidase activity and in petioles for polyphenol oxidase activity.

Similar to our experiments, both low light and high salinity reduced relative growth rate of the annual halophyte Aster laurentianus (Reynolds et al., 2001). However, the effect of both factors was strictly additive with no significant interaction between them. In contrast to the present results, the growth rate of a salt tolerant grass Distichlis spicata was significantly reduced by high substrate salinity when grown at low light (Kemp and Cunningham, 1981). However, salinity had no effect on growth at high light.

Most importantly, light intensity synergistically affected stimulative effect of $\mathrm{NaCl}$ on peroxidase activity in leaf petiole tissues. There was more than a five-fold increase of peroxidase activity by $100 \mathrm{mM} \mathrm{NaCl}$ treatment in high light conditions, in comparison to two-fold and four-fold increase in low and moderate light, respectively. This effect might be explained by high light-induced formation of reactive oxygen species, e.a., hydrogen peroxide in xylem tissues (Fryer et al., 2003), which may be further increased under the effect of NaCl-dependent oxidative stress (Lin and Kao, 2002). Hydrogen peroxide in turn is a well-known inducer of peroxidase activity at the level of appropriate gene expression and enzymatic protein synthesis (Lin and Kao 2002; Coego et al., 2005). However, the increase in peroxidase activity by $\mathrm{NaCl}$ was not related to growth inhibition, as it occurred also during $\mathrm{NaCl}$-dependent growth stimulation in low-light conditions.

As $H$. vulgaris grows in the wild in salt marshes with fluctuating soil salinity level and in differentially illuminated microsites, the possible ecological meaning of the presented results should be discussed in more detail. Clonal growth of $H$. vulgaris was extremely sensitive to changes in environmental variables when compared to leaf growth. It is logical to presume that the length of secondary and tertiary stolons as well as the number of respective ramets, reflects branching intensity of the clonal plant. Increased branching due to favourable conditions is a well-documented response of clonal plants (Alpert, 1991; Evans, 1992; Evans and Cain, 1995). Secondary and tertiary clonal growth of Hydrocotyle bonariensis was shown to be positively dependent on high nitrogen content (Evans, 1988). In the present experiment, formation of secondary stolons was almost completely suppressed by low light, while formation of primary stolons was considerably less affected. Lower responsiveness of primary clonal characteristics to decrease of light intensity in comparison to secondary characteristics might be related to the particular conditions of the experiment, e.g., that plants were propagated from the initial material established in moderate light affecting primary clonal growth within the first weeks of the treatment. Variation in branch production was described for $H$. bonariensis in conditions of a salt gradient (Evans and Whitney, 1992). As it was found also in the present experiment, internode length of clonal plants is feature with low variability. Only changes of light quantity and/or quality have been shown to affect internode length (Evans, 1992). In addition, weak light led to increased internode length in H. vulgaris (Dong, 1995).

More likely, responses of $H$. vulgaris to low light reflect a physiological adaptation strategy to shade conditions. In general, ramets of clonal plants survive in suboptimal microhabitats (i.e. high soil salinity) by connections to ramets in more optimal conditions (Pennings and Callaway, 2000). Physiological integration of clonal plants, together with foraging, is an adaptive feature in highly heterogeneous coastal habitats. The largest leaves with the longest petioles having high competitive ability due to a large photosynthetic area and light availability were found for $H$. vulgaris plants in moderate light conditions. However, in these conditions, the number of both primary and secondary ramets and length of secondary stolons was not maximal. Consequently, at high light intensity, material is invested in clonal growth, allowing exploration of microenvironment and effective foraging for resources, while at moderate to low light intensity, leaf growth is stimulated. Partially shaded microhabitats are used by $H$. vulgaris plants to avoid competition with faster growing shade avoiding species. When foraging ramets reach more illuminated microhabitats, leaf growth is inhibited due to investment in clonal growth. It has been shown previously that small-scale heterogeneity in soil characteristics affect habitat selection of clonal plants (Roiloa and Retierto, 2006). This could be especially important in heterogeneous light environments, allowing some ramets of a clone to be placed in shade to obtain mineral nutrients while the connected ramets exploit neighbouring high light conditions (Xiao et al., 2007).

When soil salinity temporarily increases due to soil inundation with sea water, relatively low $\mathrm{NaCl}$ in shaded microhabitats (as under tree canopies) stimulates leaf growth, allowing for increased photosynthetic carbon fixation. In better illuminated microhabitats (as under herbaceous vegetation) increased soil salinity leads to strong growth inhibition of less salinity-tolerant species; therefore, a relatively minor decrease of petiole length of $H$. vulgaris does not result in significantly lower light availability. In contrast, clonal growth of $H$. vulgaris in shaded places is not negatively affected by $\mathrm{NaCl}$, with secondary clonal growth even being stimulated in low and moderate light conditions. Inability to resist against $\mathrm{NaCl}$-dependent growth inhibition in 
high light conditions most probably was related to stimulation of formation of reactive oxygen species by $\mathrm{NaCl}$. In saline soil conditions, osmotic disbalance in plant tissues has been shown to lead to endogenous oxidative stress (Khan et al., 2010) with reactive oxygen species directly participating in growth inhibition (Lin and Kao, 2001). In addition, direct association between the enzymatic antioxidative system and differential growth of plants due to salinity has been demonstrated (Bernstein et al., 2010). Soil flooding is another factor to consider when studying physiology of salinity responses in salt marsh plants, as salinity tolerance is greatly affected by soil water content (Rogers and West, 1993). Oxygen shortage in flooded soil conditions represents an additional stress factor with numerous effects on redox metabolism and physiological functions (DeLaune et al., 1987; Pezeshki, 2001).

While aspects of resource heterogeneity were not studied in the present experiments, it is tempting to speculate that in natural conditions $H$. vulgaris plants use high morphological and biochemical plasticity to adapt locally to particular light conditions and soil salinity. The existence of different endogenous control mechanisms during $H$. vulgaris response to light and $\mathrm{NaCl}$ at the level of leaf growth, clonal growth and oxidative metabolism could be proposed. Also, the particular effect of light vs. light-dependent effect of $\mathrm{NaCl}$ possibly could be due to different mechanisms. Thus, the growth-stimulative effect of $\mathrm{NaCl}$ in low-light conditions did not depend on the degree of low-light induced growth inhibition, clearly indicating the decoupling of regulation mechanisms. To make the situation even more complicated, also leaf blade and leaf petiole tissues of $H$. vulgaris showed different light-dependent $\mathrm{NaCl}$ effect on oxidative enzyme activity, with relatively low activity of both enzymes in petioles, altogether pointing to concomitant induction of different regulatory pathways in conditions of high soil salinity.

In conclusion, $H$. vulgaris responded to changes in environmental conditions (i.e. shade and increased substrate salinity) by high morphological and biochemical plasticity. The obtained results clearly show that the effect of increased substrate salinity on morphological and biochemical characteristics of plants should be analysed in respect to particular light conditions. This could be especially important for a shade tolerant species like $H$. vulgaris.

\section{ACKNOWLEDGMENTS}

This study was supported by the Latvian State Research Programme "The value and dynamic of Latvia's ecosystems under changing climate" (EVIDEnT) project and the University of Latvia project "Biological diversity - impacts, functions and protection". The authors declare that they have no conflict of interest.

\section{REFERENCES}

Backhausen, J. E., Klein, M., Klocke, M., Jung, S., Scheibe, R. (2005). Salt tolerance of potato (Solanum tubersoum L. var. Desirée) plants depends on light intensity and air humidity. Plant Sci., 169, 229-237.
Ben Ahmed, C., Ben Rouina, B., Boukhris, M. (2008). Changes in water relations, photosynthetic activity and proline accumulation in one-year-old olive trees (Olea europaea $\mathrm{L}$. cv. Chemlali) in response to $\mathrm{NaCl}$ salinity. Acta Physiol. Plant., 30, 553-560.

Bernstein, N., Shoresh, M., Xu., Y., Huang, B. (2010). Involvement of the plant antioxidative response in the differential growth sensitivity to salinity of leaves vs roots during cell development. Free Radic. Biol. Med., 49, 1161-1171.

Broetto, F., Duarte, H. M., Lüttge, U. (2007). Responses of chlorophyll fluorescence parameters of the facultative halophyte and $\mathrm{C}_{3}$-CAM intermediate species Mesembryanthemum crystallinum to salinity and high irradiance stress. J. Plant Physiol., 164, 904-912.

Coego, A., Ramirez, V., Ellul, P., Mayda, E., Vera, P. (2005). The $\mathrm{H}_{2} \mathrm{O}_{2}$-regulated $E p 5 C$ gene encodes a peroxidase required for bacterial speck susceptibility in tomato. Plant J., 42, 283-293.

Cornelissen, J. H. C., Song, Y.-B., Yu, F.-H., Dong, M. (2014). Plant traits and ecosystem effects of clonality: A new research agenda. Ann. Bot., 114, 369-376.

Dawe, C. E., Reekie, E. G. (2007). The effects of flooding regime on the rare Atlantic coastal plain species Hydrocotyle umbellata. Can. J. Bot., 85, 167-174.

DeLaune, R. D., Pezeshki, S. R., Patrick W. H. Jr (1987). Response of coastal plants to increase in submergence and salinity. J. Coastal Res., 3, 535-546.

Dong, M. (1995). Morphological responses to local light conditions in clonal herbs from contrasting habitats, and their modification due to physiological integration. Oecologia, 101, 282-288.

Evans, J. P. (1988). Nitrogen translocation in a clonal dune perennial, Hydrocotyle bonariensis. Oecologia, 77, 64-68.

Evans, J. P. (1991). The effect of resource integration on fitness related traits in a clonal dune perennial, Hydrocotyle bonariensis. Oecologia, 86, 268-275.

Evans, J. P., Cain, M. L. (1995). A spatially explicit test of foraging behavior in a clonal plant. Ecology, 76, 1147-1155.

Evans, J. P., Whitney, S. (1992). Clonal integration across a salt gradient by a nonhalophyte, Hydrocotyle bonariensis (Apiaceae). Amer. J. Bot., 79, 1344-1347.

Fryer, M. J., Ball, L., Oxborough, K., Karpinski, S., Mullineaux, P. M., Baker, N. R. (2003). Control of Ascorbate Peroxidase 2 expression by hydrogen peroxide and leaf water status during excess light stress reveals a functional organisation of Arabidopsis leaves. Plant J., 33, 691-705.

Gapinska, M., Sklodowska, M., Gabara, B. (2008). Effect of short- and long-term salinity on the activities of antioxidative enzymes and lipid peroxidation in tomato roots. Acta Physiol. Plant., 30, 11-18.

Gauillard, F., Richard-Forget, F., Nicolas, J. (1993). New spectrophotometric assay for polyphenol oxidase activity. Anal. Biochem., 215, 59-65.

Gommers, C. M. M., Visser, E. J. W., St Onge, K. R., Voesenek, L. A. C. J., Pierik, R. (2013). Shade tolerance: When growing tall is not an option. Trends Plant Sci., 18, 65-71.

Huber, H., Wiggerman, L. (1997). Shade avoidance in the clonal herb Trifolium fragiferum: A field study with experimentally manipulated vegetation height. Plant Ecol., 130, 53-62.

Hussner, A., Lösch, R. (2007). Growth and photosynthesis of Hydrocotyle ranunculoides L. fil. in Central Europe. Flora, 202, 653-660.

Karlsons, A., Osvalde, A., Ievinsh, G. (2011). Growth and mineral nutrition of two Triglochin species from saline wetlands: Adaptation strategies to conditions of heterogeneous mineral supply. Environ. Exp. Biol., 9, 83-90.

Karlsons, A., Osvalde, A., N̦ečajeva, J., Ievinsh, G. (2008). Changes of nutritional status of coastal plants Hydrocotyle vulgaris and Aster tripolium at elevated soil salinity. Acta Univ. Latv., 745, 165-177.

Kemp, P. R., Cunningham, G. L. (1981). Light, temperature and salinity effects on growth, leaf anatomy and photosynthesis of Distichlis (L.) Greene. Amer. J. Bot., 68, 507-516. 
Khan, M. N., Siddiqui, M. H., Mohammad, F., Naeem, M., Khan, M. M. A. (2010). Calcium chloride and gibberellic acid protect linseed (Linum usitatissimum $\mathrm{L}$.) from $\mathrm{NaCl}$ stress by inducing antioxidative defence system and osmoprotectant accumulation. Acta Physiol. Plant. 32, 121-132.

Knight, T. M., Miller, T. E. (2004). Local adaptation within a population of Hydrocotyle bonariensis. Evol. Ecol. Res., 6, 103-114.

Leeflang, L., During, H. J., Werger, M. J. A. (1998). The role of petioles in light acquisition by Hydrocotyle vulgaris $\mathrm{L}$. in a vertical light gradient. Oecologia, 117, 235-238.

Lin, C. C., Kao, C. H. (2001). Cell wall peroxidase activity, hydrogen peroxide level and $\mathrm{NaCl}$-inhibited root growth of rice seedlings. Plant Soil, 230, 135-143.

Lin, C. C., Kao, C. H. (2002). Osmotic stress-induced changes in cell wall peroxidase activity and hydrogen peroxide level in roots of rice seedlings. Plant Growth Reg., 37, 177-184.

Liu, Y., Schieving, F., Stuefer, J. F., Anten, N. P. R. (2007). The effects of mechanical stress and spectral shading on the growth and allocation of ten genotypes of a stoloniferous plants. Ann. Bot., 99, 121-130.

Longstreth, D. J., Strain, B. R. (1977). Effects of salinity and illumination on photosynthesis and water balance of Spartina alterniflora Loisel. Oecologia, 31, 191-199.

López-Hoffman, L., Anten, N. P. R., Martínez-Ramos, M., Ackerly, D. D. (2007). Salinity and light interactively affect neotropical mangrove seedlings at the leaf and whole plant level. Oecologia, 150, 545-556.

Maehly, A. C., Chance, B. (1954). The assay of catalases and peroxidases. In: Glick, D. (ed.). Methods of Biochemical Analysis. Vol. I. Interscience Publishers, New York, pp. 357-424.

Miao, L.-H., Ji, M.-C., Wang, Y.-Y., Qiao, D.-D., Chen, Y.-C. (2011). Study on invasion risk of Hydrocotyle vulgaris as an alien species in wetlands. $J$. Zhejiang Univ. Agric. Life Sci., 37, 425-431.

Mommer, L., de Kroon, H., Pierik, R., Bögemann, G. M., Wisser, E. J. W. (2005). A functional comparison of acclimated to shade and submergence in two terrestrial plant species. New Phytol., 167, 197-206.

Muchate, N. S., Nikalje, G. C., Rajurkar, N. S., Suprasanna, P., Nikam, T. D. (2016). Physiological resposnes of the halophyte Sesuvium potrulacastrum to salt stress and their relevance for saline soil bio-reclamation. Flora, 224, 96-105.

Neumann, P. (1997). Salinity resistance and plant growth revisited. Plant Cell Environ., 20, 1193-1198.

Packham, J. R., Willis, A. J. (1997). Ecology of Dunes, Salt Marsh and Shingle. Chapman \& Hall, London. 336 pp.

Pennings, S. C., Callaway, R. M. (2000). The advantages of clonal integration under different ecological conditions: a communitywide test. Ecology, 81, 709-716.

Received 29 November 2018

Accepted in the final form 5 December 2019
Peterson, A. G., Chesson, P. (2002). Short-term fitness benefits of physiological integration in the clonal herb Hydrocotyle peduncularis. Austral Ecol., 27, 647-657.

Pezeshki, S. R. (2001). Wetland plant responses to soil flooding. Environ. Exp. Bot., 46, 299-312.

Reich, P. B., Tjoelker, M. G., Walters, M. B., Wanderklein, D. W., Buschena, C. (1998). Close association of RGR, leaf and root morphology, seed mass and shade tolerance in seedlings of nine boreal tree species grown in high and low light. Funct. Ecol., 12, 327-338.

Reynolds, C. E., Houle, G., Marquis, C. (2001). Light and salinity affect growth of the salt marsh plant Aster laurentianus. New Phytol., 149, $441-448$.

Richards, C. L., Hamrick, J. L., Donovan, L. A., Mauricio, R. (2004). Unexpectedly high clonal diversity of two salt marsh perennials across a severe environmental gradient. Ecol. Lett., 7, 1155-1162.

Rochelle, C. (2005) Interactive effects of salinity and irradiance on photoprotection in acclimated seedlings of two sympatric mangroves. Trees, 19, 596-606.

Rogers, M. E., West, D. W. (1993). The effects of rootzone salinity and hypoxia on shoot and root growth in Trifolium species. Ann. Bot., 72, 503-509.

Roiloa, S. R., Retuerto, R. (2006). Small-scale heterogeneity in soil quality influences photosynthetic efficiency and habitat selection in a clonal plant. Ann. Bot., 98, 1043-1052.

Santamaría, L. (2002). Why most aquatic plants widely distributed? Dispersal, clonal growth and small-scale heterogeneity in a stressful environment. Acta Oecol., 23, 137-154.

Shevyakova, N. I., Rakitin, V. Y., Stetsenko, L. A., Aronova, E. E., Kuznetsov, V. V. (2006). Oxidative stress and fluctuations of free and conjugated polyamines in the halophyte Mesembryanthemum crystallinum L. under $\mathrm{NaCl}$ salinity. Plant Growth Reg., 50, 69-78.

Smith, H. (1982). Light quality, photoperception and plant strategy. Annu. Rev. Plant Physiol., 33, 481-518.

Sosnová, M., van Diffelen, R., Klimešová, J. (2010). Distribution of clonal growth forms in wetlands. Aquatic Bot., 92, 33-39.

Ungar, I. A. (1998). Are biotic factors significant in influencing the distribution of halophytes in saline habitats? Bot. Rev., 64, 176-199.

Van Zandt, P. A., Tobler, M. A., Mouton, E., Hasenstein, K. H., Mopper, S. (2003). Positive and negative consequences of salinity stress for the growth and reproduction of the clonal plant, Iris hexagona. J. Ecol., 91, 837-846.

Xiao, K., Yu, D., Xu, X., Xiong, W. (2007). Benefits of clonal integration between interconnected ramets of Vallisneria spiralis in heterogeneous light environments. Aquatic Bot., 86, 76-82.

\section{GAISMAS APSTĀKLII IETEKMĒ NaCl-INDUCĒTĀS FIZIOLOG̣ISKĀS ATBILDES REAKCIJAS KLONĀLAJAI AUGU SUGAI HYDROCOTYLE VULGARIS}

Lai saprastu, vai atšḳirīgās gaismas intensitātes var ietekmēt klonālās augu sugas atbildes reakcijas uz augsnes sāḷmu, pētīja divu NaCl koncentrāciju substrātā ilglaicīgu ietekmi uz lapu augšanu, klonālo plastiskumu un oksidatīvo enzīmu aktivitāti parastās vairoglapes (Hydrocotyle vulgaris L.) augiem zemas, vidējas un augstas gaismas intensitātes apstākḷlos. H. vulgaris parādīja ēnas izturīgas sugas pazīmes, jo gan lapu plātņu, gan lapu kātu augšanu inhibēja zemas intensitātes gaisma. Zemā gaismas intensitātē H. vulgaris augi uzrādīja halofîtiem raksturīgas īpašības, kas izpaudās kā lapu plātnes un lapu kāta augšanas stimulācija $\mathrm{NaCl}$ ietekmē, it īpaši zemā koncentrācijā. Palielināts sāḷums veicināja sekundāro klonālo augšanu zemā gaismā un, $25 \mathrm{mM} \mathrm{NaCl}$ apstrādes gadījumā, arī vidējā gaismā. Augstas gaismas apstākḷıs novēroja vairāk kā pieckārtīgu $\mathrm{NaCl}$ inducētu peroksidāzes aktivitātes pieaugumu, salīdzinot ar divkārtīgu un četrkārtīgu pieaugumu atbilstoši zemā un vidējā gaismā. Varētu domāt, ka $H$. vulgaris reakcija uz gaismu un $\mathrm{NaCl}$ ir atkarīga no dažādiem endogēnās kontroles mehānismiem lapu augšanas, klonālās augšanas un oksidatīvā metabolisma līmenī. Sīkāk analizēta iegūto rezultātu iespējamā ekoloğiskā nozīme. 